\title{
The inhibitory effect of cadmium and/or mercury on soil enzyme activity, basal respiration, and microbial community structure in coal mine-affected agricultural soil
}

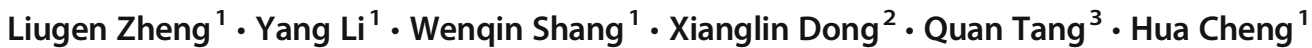

Received: 19 October 2018 / Accepted: 26 April 2019 / Published online: 6 May 2019

(C) Università degli studi di Milano 2019

\begin{abstract}
Purpose The $\mathrm{Cd}$ and $\mathrm{Hg}$ contents in soils can be elevated due to coal mining. To estimate the effects of these two heavy metals on soil enzymes and the key microbial groups, coal mine-affected agricultural soils were cultured for 30 days with Cd and/or $\mathrm{Hg}$. Methods Soil enzyme activities were measured by a colorimetric method, and microbial abundance was assessed according to real-time quantitative PCR analysis of the 16S rRNA and 18S rRNA genes. In addition, the microbial communities were analyzed by Illumina sequencing.

Results Heavy metals inhibited soil enzyme activities. For example, both $\mathrm{Cd}$ and $\mathrm{Hg}$ decreased $25.52-34.89 \%$ of the soil catalase activity; the highest level of $\mathrm{Hg}\left(30 \mathrm{mg} \mathrm{kg}^{-1}\right)$ decreased $76.50-89.88 \%$ of the soil urease activity and $85.60-92.92 \%$ of the soil dehydrogenase activity; and the soil acid phosphatase activity significantly decreased by $15.18-32.64 \%$ under all the levels of Cd and decreased 17.09-30.32\% under the high levels of the $\mathrm{Cd}-\mathrm{Hg}$ combination $\left(>3 \mathrm{mg} \mathrm{kg}^{-1}\right)$. In addition, increased Cd levels affected bacterial number more than fungal abundance; however, addition of $\mathrm{Hg}$ alone decreased the bacterial number but increased the fungal abundance. Furthermore, the bacterial communities but not fungal communities were altered by heavy metals. A total of 23 highly sensitive genera and 16 highly resistant genera were identified. The sensitive genera were assigned to Actinobacteria, Acidobacteria, Candidate division WS3, Chloroflexi, Gemmatimonadetes, Proteobacteria, and Thermotogae, while the resistant genera were affiliated to Bacteroidetes and Proteobacteria.

Conclusion Soils containing the highest level of the combination of $\mathrm{Cd}$ and $\mathrm{Hg}$ exhibited the lowest soil enzyme activities; bacterial communities were more sensitive to heavy metal contamination than fungi.
\end{abstract}

Keywords Coal mine $\cdot$ Agricultural soil $\cdot$ Soil enzymes $\cdot$ Bacterial community $\cdot$ Fungal communities

\section{Introduction}

$\mathrm{Cd}$ and $\mathrm{Hg}$ are two of the most toxic heavy metals and pose a serious threat to soil ecosystems. Accumulation of these toxic

Electronic supplementary material The online version of this article (https://doi.org/10.1007/s13213-019-01478-3) contains supplementary material, which is available to authorized users.

Liugen Zheng

lgzheng@ustc.edu.cn

1 School of Resources and Environmental Engineering, Anhui University, Hefei, China

2 Geological Survey Division, Huaibei Coal Mining Group Corporation, Huaibei 235001, China

3 School of Life Sciences, Anhui University, Hefei, China heavy metals occurs mainly during natural soil formation (dos Santos et al. 2017), and anthropogenic deposits originate from sewage irrigation, sludge application, solid waste treatment, automobile exhausts, industrial activities (Jan et al. 2010), and mining (Šajn et al. 2013; Li et al. 2014). It is well known that these heavy metals have negative effects on biological functions in soil, including soil enzyme activity (Khan et al. 2010; Pan and Yu 2011), microbial abundance (Chen et al. 2014), microbial activity (Chodak et al. 2013; Chen et al. 2015), and microbial community structure (Khan et al. 2010; Frey and Rieder 2013).

Microorganisms in soils exhibit a certain adaptability to heavy metals. However, identification of an indicator of heavy metal pollution in soils remains challenging. Previous studies have found that soil enzymes can facilitate soil chemical reactions and metabolic processes, such as biogeochemical nutrient cycling (Moreno et al. 2003). These soil enzymes are 
sensitive to heavy metal contamination (Xian et al. 2015) and are often used to estimate the adverse effects of pollutants on soil quality (Wang et al. 2007; Gao et al. 2010). For example, inhibition of urease or phosphatase activity by heavy metals has been reported (Pan and Yu 2011). Meanwhile, heavy metals also have considerable effects on the abundance and composition of microbial communities (Pan and Yu 2011; Frey and Rieder 2013), which ultimately lead to changes in soil microbial activities, including soil basal respiration and enzyme activity (Pan and Yu 2011; Xian et al. 2015).

The $\mathrm{Cd}$ and $\mathrm{Hg}$ levels in soils are particularly elevated due to coal mining in the Linhuan subsidence of Huaibei Coalfield, Anhui Province, China. The mean concentrations of $\mathrm{Cd}$ and $\mathrm{Hg}$ were $0.26 \mathrm{mg} \mathrm{kg}^{-1}$ and $0.04 \mathrm{mg} \mathrm{kg}^{-1}$, respectively, which were as high as 3.2 and 2.9 times the background values of the surface soil of Huaibei City according to our previous research (Shang et al. 2016). Therefore, in this region, $\mathrm{Cd}$ and $\mathrm{Hg}$ are likely to affect both soil microbial diversity and soil microbial processes because heavy metals can have long-term hazardous effects on soil ecosystems and adverse effects on soil biological processes (Lee et al. 2002; Pérez-de-Mora et al. 2006). Although several studies found that polymetal co-contamination could result the decrease of actinomycetes ( $\mathrm{Xu}$ et al. 2019), and Proteobacteria, Firmicutes, and Acidobacteria were most altered by heavy metal contents (Frey and Rieder 2013; Deng et al. 2015; Jiang et al. 2019). Few studies have identified microorganisms that exhibit resistance or sensitivity to these two metals and could be used as indicators of heavy metal pollution in soils. Therefore, in the present study, we determined the effects of increasing $\mathrm{Cd}$ and $\mathrm{Hg}$ concentrations on the soil microbial communities in coal mining-affected agricultural soil and aimed to screen groups that were resistant or sensitive to $\mathrm{Cd}$ and $\mathrm{Hg}$ contaminations.

\section{Materials and methods}

\section{Soil characteristics}

Soil samples were collected from the top $0-20 \mathrm{~cm}$ of the Linhuan subsidence of Huaibei Coalfield, Anhui Province, China (latitude $\mathrm{N} 33^{\circ} 36^{\prime}$, longitude $\mathrm{E} 116^{\circ} 36^{\prime}$ ), which is located in the warm-temperate, semihumid, monsoon climate zone. The collected soil samples were stored in a polyethylene bag and transported in ice to the laboratory, where the samples were sieved through a $2-\mathrm{mm}$ mesh and stored at $-20^{\circ} \mathrm{C}$. The soil properties were as follows: $\mathrm{pH}, 6.82$; soil organic matter content, $20.64 \mathrm{~g} \mathrm{~kg}^{-1}$; total nitrogen content, $4.5 \mathrm{~g} \mathrm{~kg}^{-1}$; available potassium content, $140.5 \mathrm{mg} \mathrm{kg}^{-1}$; available phosphorus content, $4.28 \mathrm{mg} \mathrm{kg}^{-1}$; EC, $185.5 \mu \mathrm{s} \mathrm{cm}^{-1}$; $\mathrm{Cd}_{\mathrm{T}}$ (the subscript $\mathrm{T}$ indicates total content), $0.30 \mathrm{mg} \mathrm{kg}^{-1} ; \mathrm{Cr}_{\mathrm{T}}, 90.11 \mathrm{mg} \mathrm{kg}^{-1}$;
$\mathrm{Cu}_{\mathrm{T}}, 25.66 \mathrm{mg} \mathrm{kg}^{-1} ; \mathrm{Ni}_{\mathrm{T}}, 42.67 \mathrm{mg} \mathrm{kg}^{-1} ; \mathrm{Pb}_{\mathrm{T}}, 34.83 \mathrm{mg} \mathrm{kg}^{-1}$; $\mathrm{Zn}_{\mathrm{T}}, 69.20 \mathrm{mg} \mathrm{kg}^{-1}$; and $\mathrm{Hg}_{\mathrm{T}}, 0.0633 \mathrm{mg} \mathrm{kg}^{-1}$.

\section{Experimental setup}

The samples were adjusted to $40 \%$ water-holding capacity with deionized water and preincubated at $25{ }^{\circ} \mathrm{C}$ for 7 days. $\mathrm{Cd}$ and $\mathrm{Hg}$ were added to the soil as an aqueous mixture of $\mathrm{CdCl}_{2}$ and $\mathrm{HgCl}_{2}$. A control group (ck, sterile water microcosms) and nine test groups (each test group with three repeats) were examined. In the $\mathrm{Cd}$ test, concentration gradients were set up as follows: $0.3 \mathrm{mg} \mathrm{kg}^{-1}(\mathrm{Cd} 0.3), 3 \mathrm{mg} \mathrm{kg}^{-1}(\mathrm{Cd} 3)$, and $30 \mathrm{mg} \mathrm{kg}^{-1}(\mathrm{Cd} 30)$; in the $\mathrm{Hg}$ test, the concentration gradients were as follows: $0.3 \mathrm{mg} \mathrm{kg}^{-1}$ ( $\left.\mathrm{Hg} 0.3\right), 3 \mathrm{mg} \mathrm{kg}^{-1}$ ( $\mathrm{Hg} 3)$, and $30 \mathrm{mg} \mathrm{kg}^{-1}(\mathrm{Hg} 30)$; and in the $\mathrm{Cd}$ and $\mathrm{Hg}$ test, the concentration gradients were as follows: $0.3 \mathrm{mg}$ of $\mathrm{Cd}$ and $0.3 \mathrm{mg}$ of $\mathrm{Hg} \mathrm{kg}^{-1}(\mathrm{CdHg} 0.3), 3 \mathrm{mg}$ of $\mathrm{Cd}$ and $3 \mathrm{mg}$ of $\mathrm{Hg} \mathrm{kg}^{-1}$ (CdHg3), $30 \mathrm{mg}$ of $\mathrm{Cd}$ and $30 \mathrm{mg}$ of $\mathrm{Hg} \mathrm{kg}^{-1}$ $(\mathrm{CdHg} 30)$. A total of 30 independent incubations were performed. The treated soils were placed in plastic bags and mixed thoroughly, and then, the soils were kept at $25^{\circ} \mathrm{C}$ for $24 \mathrm{~h}$ to obtain a uniform distribution of the metal and an equilibrium between $\mathrm{Cd}, \mathrm{Hg}$, and soil binding sites. Then, the soils $(500 \mathrm{~g})$ were transferred into $1000-\mathrm{mL}$ plastic jars and covered with the supplied air-permeable caps throughout the experiment to minimize evaporation but permit aeration. The microcosms were incubated in the dark at $25^{\circ} \mathrm{C}$ and $60 \%$ external humidity in climatic chambers. Water loss was determined every other day by weight and was compensated by addition of sterile water. Destructive sampling was performed in triplicate after incubation of the microcosms for 30 days.

\section{Enzyme activities and basal respiration assays}

Soil urease activity was determined by the indophenol-based colorimetric method, and the $\mathrm{NH}_{4}{ }^{+}$released by ureasemediated enzymatic hydrolysis of urea was determined colorimetrically at $578 \mathrm{~nm}$ (Guan 1986). Acid phosphatase activity was measured by the buffer method, and the $p$-nitrophenol (PNP) levels in the filtrate were determined colorimetrically at $410 \mathrm{~nm}$ (Guan 1986). Dehydrogenase activity was tested by reduction of 2,3,5-triphenyltetrazolium chloride (TTC), and the triphenyl formazan (TPF) released was extracted with methanol and assayed at $485 \mathrm{~nm}$ (Guan 1986). Catalase activity was measured by the titration method (Guan 1986), and soil basal respiration (SBR) $\left(\mathrm{CO}_{2}\right.$ production by incubation for $24 \mathrm{~h}$ at $25{ }^{\circ} \mathrm{C}$ ) was measured by the sodium hydroxide absorption method (Xu et al. 2019).

\section{Illumina sequencing}

Total DNA was extracted from each sample with a soil extraction kit (E.Z.N.A. Soil DNA Kit, Omega) 
according to the manufacturer's instructions. The V3V4 region of the $16 \mathrm{~S}$ rRNA gene of each sample was amplified by the $338 \mathrm{~F} / 806 \mathrm{R}$ primer pair $\left(338 \mathrm{~F}\right.$ : $5^{\prime}-\mathrm{ACT}$ CCT ACG GGA GGC AGC A-3' and 806R: 5'-GGA CTA CHV GGG TWT CTA AT-3'). The primer pair 0817F (5'-TTA GCA TGG AAT RRA ATA GGA-3') and 1196R (5'-TCT GGA CCT GGT GAG TTT CC$\left.3^{\prime}\right)$ was used for amplification of the $18 \mathrm{~S}$ rRNA gene. Primers were tagged with unique barcodes for each sample. Each sample was amplified in triplicate, and the products were pooled in a single tube. Negative controls using sterilized water instead of soil DNA extract were included to check for primer or sample DNA contamination. The quality and concentrations of the purified barcoded PCR products were determined using a NanoDrop spectrophotometer. The MiSeq Reagent Kit v2 was used for sequencing by an Illumina MiSeq PE250 for bacteria and PE300 for fungi. All clean sequence data have been deposited in the GenBank shortread archive under accession code SRP067940.

Clean sequencing data were obtained using Trimmomatic and FLASH software as follows: the data were filtered when the quality value of the reads was below 20 bases. A 50-bp window was used, and when the average quality value of the window was less than 20 , the bases at the lower end of the window and reads that were less than $50 \mathrm{bp}$ in size after quality control were filtered; based on the overlap between paired-end (PE) reads, the paired reads were merged into a single sequence, and the minimum overlap length was $10 \mathrm{bp}$. The largest allowable false matching ratio for the splicing overlap area of the sequences was 0.2 , and the unmatched sequences were then screened out. Operational taxonomic units (OTUs) were clustered with 97\% similarity, and picking and taxonomy assignments were performed with the "pick_closed_reference_otus.py" command according to the SILVA database for subsequent analysis. According to taxonomic assignment, OTUs assigned to nonfungi were removed.

\section{Real-time quantitative PCR analysis of 16S rRNA and $18 S$ rRNA genes}

Real-time quantitative analysis of the 16S rRNA and $18 \mathrm{~S}$ rRNA genes was performed on a CFX96 optical real-time detection system (Bio-Rad Laboratories Inc., Hercules, CA, USA). The primer pairs $338 \mathrm{~F} / 806 \mathrm{R}$ and $0817 \mathrm{~F} / 1196 \mathrm{R}$ were used. The reactions were performed in a $20-\mu \mathrm{L}$ mixture containing $10.0 \mu \mathrm{L}$ of SYBR Premix Ex Taq (TaKaRa), each primer at $0.5 \mu \mathrm{M}$ and $1 \mu \mathrm{L}$ of DNA template. The amplification efficiencies were $90-105 \%$, with $R^{2}$ values greater than 0.99 .

\section{Data analysis}

Data are expressed as the mean value \pm SE. Basic data calculation was performed by using Excel 2010, and graphs were drawn by using Excel 2010 and Origin 2017. One-way analysis of variance (ANOVA; Duncan, $p<0.05$ ) was used to determine the differences between groups. All the analyses were assessed by SPSS software for Windows, version 22.0 (SPSS Inc., Chicago, IL, USA). The alpha-diversity (including the Shannon index and observed species) and betadiversity (Bray-Curtis distance) metrics of the bacterial and fungal communities were calculated based on a randomly selected subset of 4513 sequences per sample. A Bray-Curtis distance matrix was calculated from square root-transformed Illumina sequencing data using the software programs Primer 6 v.6.1.13 and Permanova v.1.0.3 (Primer-E, UK) to study microbial community structures. To visualize differences in the bacterial and fungal soil community structures between soils with different levels of $\mathrm{Cd}$ and $\mathrm{Hg}$, nonmetric multidimensional scaling (NMDS) analyses were performed. Based on the abundances and ANOVA, 23 sensitive (decrease in the highest average abundance) and 16 resistant (increase in the highest average abundance) genera were listed and depicted in a heat map that was constructed in an $\mathrm{R}$ environment (version 3.1.2). Phylogenetic Investigation of Communities by Reconstruction of Unobserved States (PICRUSt) (http:// picrust.github.io/picrust/) was used to predict the metagenomic functional content from the sequence data. The "closed-reference" OTUs were picked using QIIME with the "pick_closed_reference_otus.py" command according to the GG reference OTUs at a specified percent identity. The "normalize_by_copy_number.py" command was performed to normalize the OTU table, and the final metagenomic functional predictions were conducted by the "predict metagenomes.py" command. The "categorize_by_function. py" command was used to collapse the predictive metagenome using KEGG pathway metadata. The differences in predictive metabolism are shown in a bar chart.

\section{Results}

\section{Effects of $\mathrm{Cd}$ and $\mathrm{Hg}$ on soil enzyme activities, soil basal respiration, and microbial abundance}

Examination of soil enzyme activities, soil respiration, and microbial abundance showed that the effects of heavy metal concentrations on soil enzyme activities differed (Fig. 1). Heavy metals did not inhibit all the soil enzyme activities at all the concentrations tested, except the soil catalase activity, which significantly decreased from 25.52 to $34.89 \%$ upon addition of $\mathrm{Cd}$ and/or $\mathrm{Hg}$. The soil urease activity in soils was inhibited at the highest $\mathrm{Hg}$ levels $\left(30 \mathrm{mg} \mathrm{Hg} \mathrm{kg}^{-1}\right.$ and 

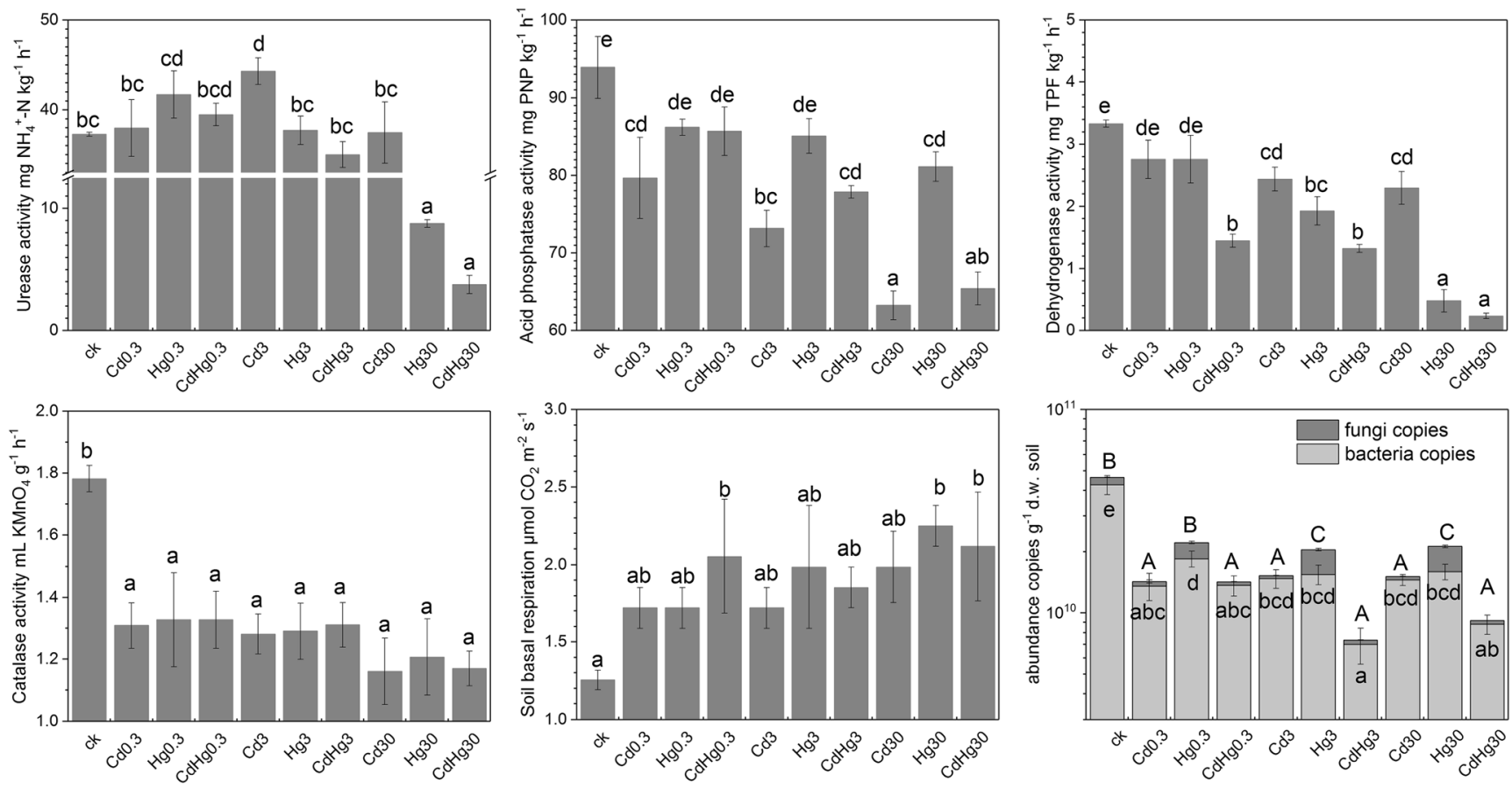

Fig. 1 Activities of soil enzymes (including urease, acid phosphatase, dehydrogenase, and catalase), soil basal respiration, and abundances of bacteria and fungi in soils. The error bars show the standard error of three

subsamples for each soil sample. Different letters indicate significant differences $(p<0.05$, Duncan)

$30 \mathrm{mg}$ of Cd and $30 \mathrm{mg}$ of $\mathrm{Hg} \mathrm{kg}^{-1}$ ), decreasing from 76.50 to $89.88 \%$. The soil acid phosphatase activity significantly decreased by $15.18-32.64 \%$ at all levels of $\mathrm{Cd}$ and decreased $17.09-30.32 \%$ at high levels of the $\mathrm{Cd}-\mathrm{Hg}$ combination. The soil dehydrogenase activity decreased under heavy metal treatment, and the lowest values were observed for $\mathrm{Hg} 30$ and $\mathrm{CdHg} 30$, decreasing $85.60 \%$ and $92.92 \%$, respectively.

With increasing concentrations of heavy metals, soil basal respiration increased under most conditions, but the microbial abundance (the total abundance of bacteria and fungi) decreased significantly from 52.27 to $80.25 \%$ (Fig. 1). High Cd levels exhibited severe toxicity against microorganisms and had stronger effects on the number of bacteria than on the number of fungi. Treatment with $\mathrm{Hg}$ alone decreased the bacterial number but increased the ratio of bacteria to fungi (Figs. 1 and 2).

\section{Effects of $\mathrm{Cd}$ and/or $\mathrm{Hg}$ on bacterial and fungal diversity}

The valid 16S rRNA gene reads associated with bacteria obtained from the samples ranged from 4513 to 38,347 in this study, and the valid $18 \mathrm{~S}$ rRNA gene reads associated with fungi ranged from 14,457 to 33,703 , both of which were normalized to 4513 for comparison of the alpha-diversity of the bacterial community. ANOVA showed that addition of low levels of heavy metals had no significant effect on the alphadiversity of the bacterial and fungal communities (Fig. 3), except for the decrease in fungal diversity and species number observed upon treatment with trace levels of $\mathrm{Cd}$ $\left(0.3 \mathrm{mg} \mathrm{kg}^{-1}\right)$. Addition of high levels of $\mathrm{Hg}\left(30 \mathrm{mg} \mathrm{kg}^{-1}\right)$ markedly decreased the Shannon diversity and observed species of the bacterial communities, and simultaneous addition of high levels of $\mathrm{Cd}\left(30 \mathrm{mg} \mathrm{kg}^{-1}\right)$ and $\mathrm{Hg}\left(30 \mathrm{mg} \mathrm{kg}^{-1}\right)$ decreased the observed species in the fungal communities. In addition, the NMDS ordinations of the bacterial communities exhibited distinct separation of samples between the control group and heavy metal-treated groups (Fig. 4), but the treatments with different levels of heavy metals were not separated from each others.

\section{Identification of the most sensitive and resistant groups}

Illumina sequencing showed that bacterial communities were dominated by Proteobacteria (Fig. 5), which accounted for $26.5-54.4 \%$ of the total bacterial sequences. Other abundant phyla found in the different treatments included Firmicutes (4.1-25\%), Actinobacteria (4.8-8.7\%), Chloroflexi (3.18.2\%), Bacteroidetes (1.9-14.1\%), Gemmatimonadetes (1.9$5.2 \%)$, Candidate division TM7 (1.0-5.6\%), and Nitrospirae $(1.7-4.9 \%)$. Compared to the controls and samples treated with low concentrations of $\mathrm{Cd}$ and $\mathrm{Hg}$, Proteobacteria, Firmicutes, and Bacteroidetes exhibited increased abundance $(p<0.05)$ upon exposure to high concentrations of $\mathrm{Cd}$ and $\mathrm{Hg}$, while Acidobacteria, Chloroflexi, Gemmatimonadetes, 
Fig. 2 Relative abundances of bacteria and fungi in soils. The percentage in the pie chart indicates the mean relative abundance

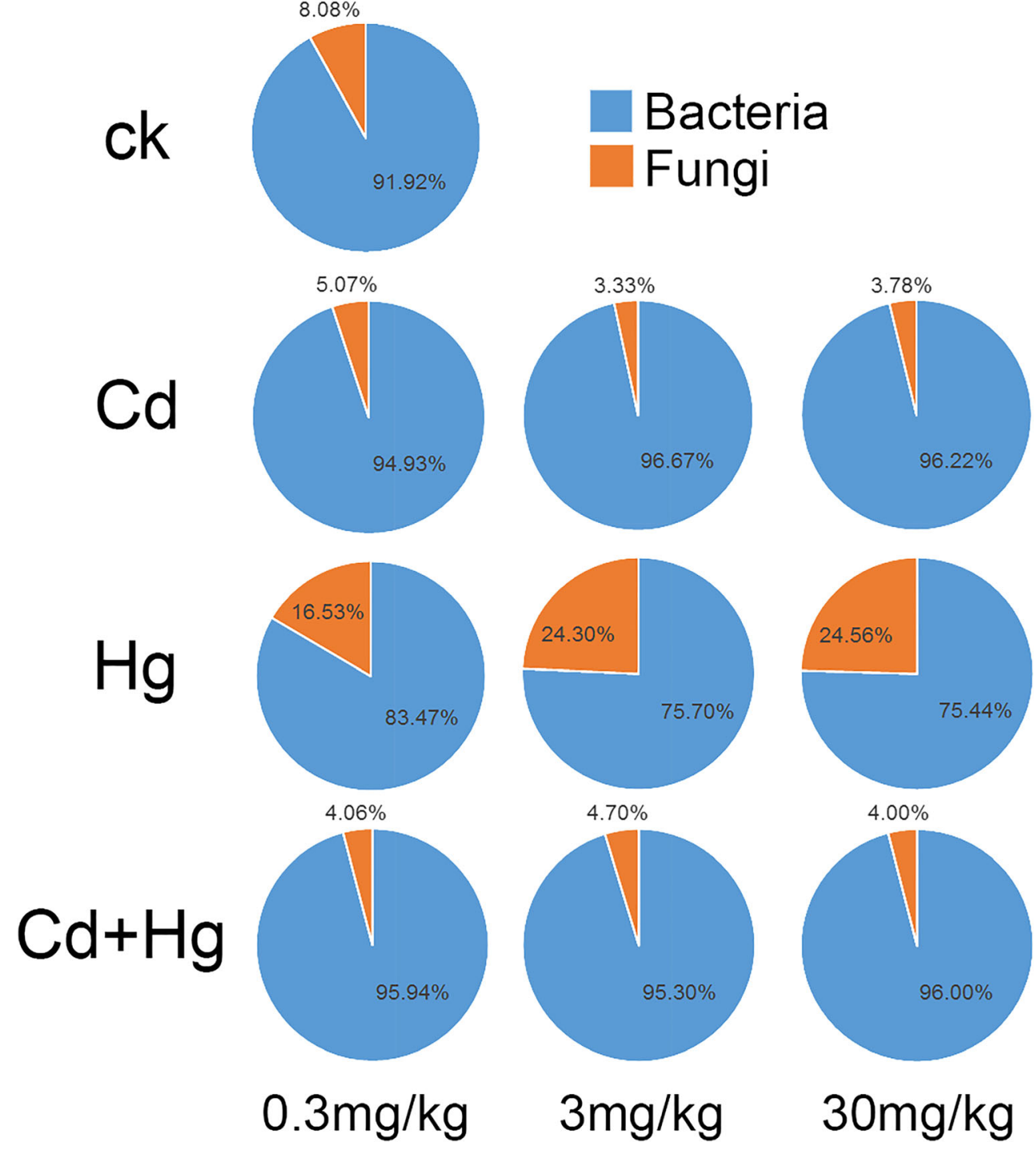



Fig. 3 Shannon diversity index and observed species of bacterial communities and fungal communities in soils. The valid bacterial and fungal sequences were normalized to 4513 for each sample. The error

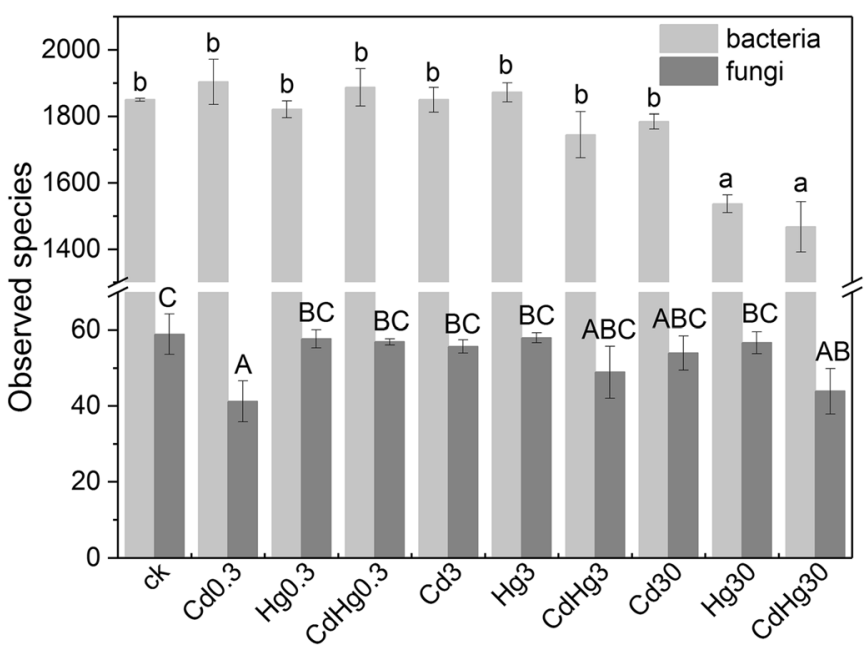

bars show the standard error of three subsamples for each soil sample. Different letters indicate significant differences $(P<0.05$, Duncan $)$ 
Bacteria



Fungi

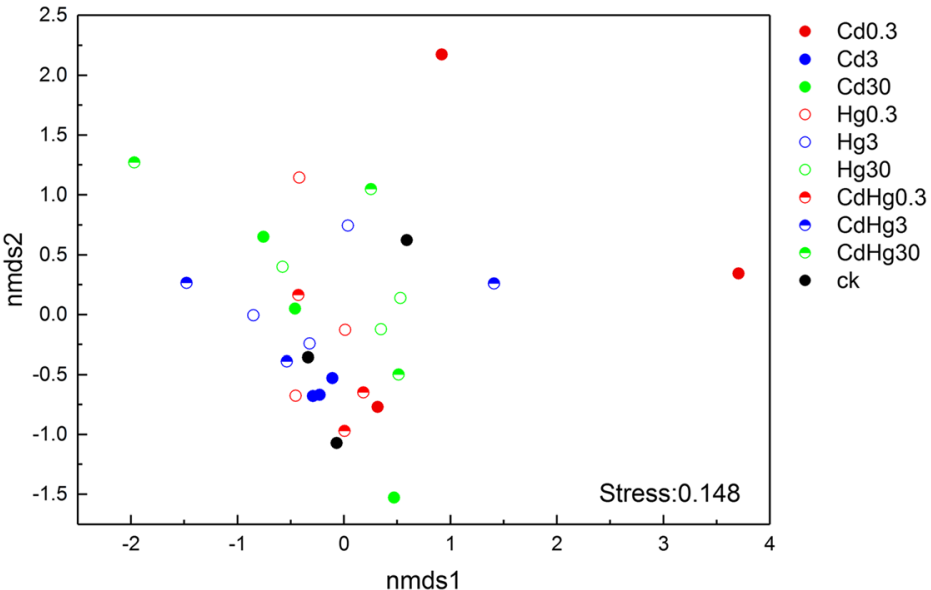

Fig. 4 Nonmetric multidimensional scaling (NMDS) analyses for the overall bacterial and fungal community composition based Bray-Curtis distance matrices of soil samples. The various colors indicate different samples; $n=3$

and Candidate division TM7 were negatively influenced by increasing $\mathrm{Cd}$ and $\mathrm{Hg}$ levels. Fungal communities were dominated by Ascomycota, which accounted for $43.7-99.3 \%$ of the total fungal sequences. Other abundant phyla found in the different treatments included Basidiomycota, Blastocladiomycota, Chytridiomycota, Glomeromycota, and Zygomycota. Basidiomycota and Blastocladiomycota were highly abundant in the $\mathrm{Cd} 0.3$ and $\mathrm{CdHg} 3$ treatments. We further analyzed the bacterial species that were sensitive or resistant to heavy metal contamination (Fig. 6). Unlike bacteria, no detoxification mechanism is known for fungi, and the effects of $\mathrm{Cd}$ and $\mathrm{Hg}$ on fungi remain poorly understood.

A heat map containing the 23 most sensitive classified genera and 16 most resistant classified genera from each treatment, exhibiting either the largest increase or the largest decrease in abundance, was used to illustrate similarities in microbial community changes across treatments (Fig. 6). The seven most sensitive phyla from each treatment, namely, Actinobacteria, Acidobacteria, Candidate division WS3, Chloroflexi, Gemmatimonadetes, Proteobacteria, and Thermotogae, contained a total of 23 genera (Fig. 6a). RB41-norank, Gemmatimonadetes-uncultured, Haliangium, and Nitrosomonadaceae-uncultured were the predominant and most sensitive genera. Bacteroidetes and Proteobacteria were the two groups in the heat map of Cd-and Hg-resistant genera (Fig. 6). Specifically, Sphingomonas, Panacagrimonas, Limnobacter, Caenimonas, and Cytophagaceae-uncultured exhibited high tolerance, and the highest proportions were observed in the $\mathrm{Hg} 30, \mathrm{Cd} 30$, and $\mathrm{CdHg} 30$ treatments. For both the sensitive and resistant groups, the $\mathrm{Hg}$ treatment shared more genera with both the $\mathrm{Hg} 30$ and $\mathrm{CdHg} 30$ treatments than other treatments. For both the sensitive and resistant groups, the $\mathrm{Hg} 30$ and $\mathrm{Cd} / \mathrm{Hg} 30$ treatments shared a relatively high number of genera.

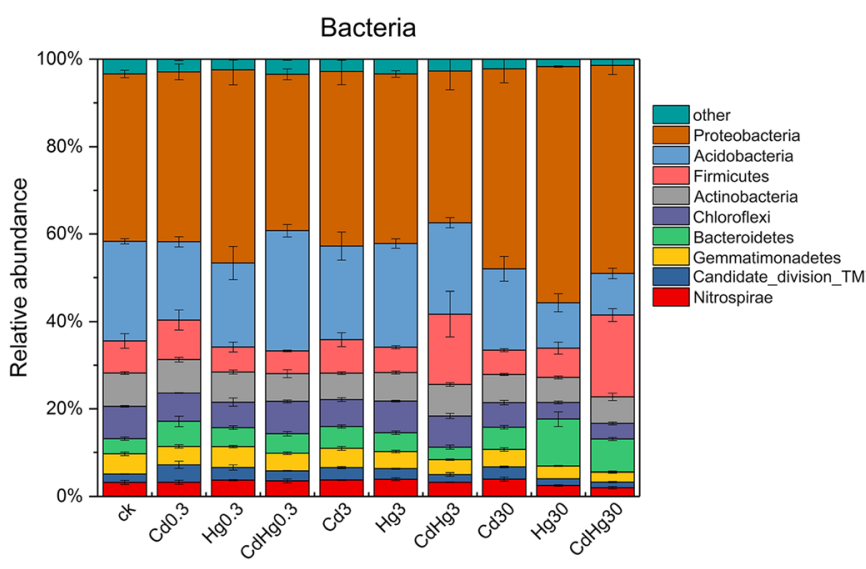

Fig. 5 Relative abundances (percentage) and abundances of the main identified bacterial and fungal taxonomic groups. For each sample, the abundances and relative abundances of the sequences assigned to a given



taxonomic unit were calculated for each of the three subsamples, and the average value was then used to represent the abundance and relative abundance of each tailing sample 


\section{(a) 23 most sensitive classified genera}

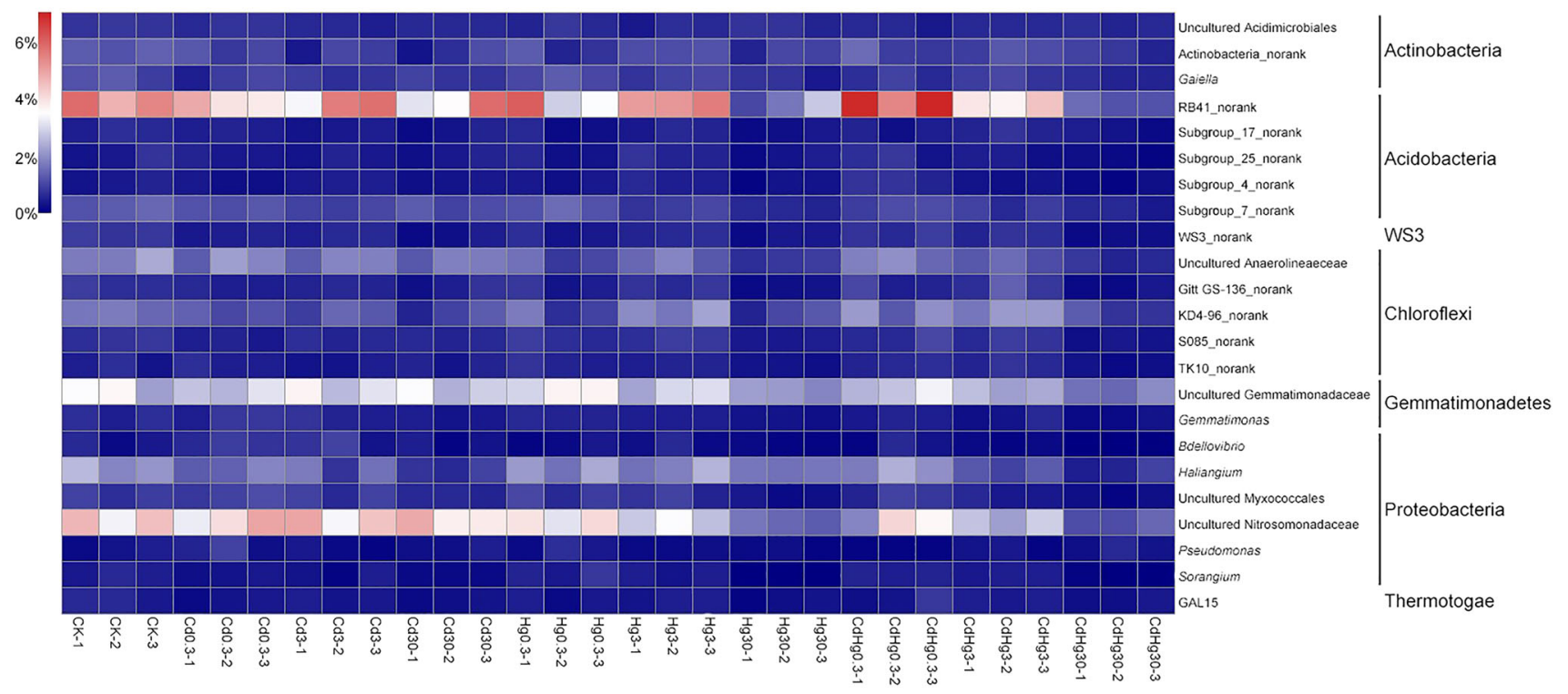

\section{(b) 16 most resistant classified genera}

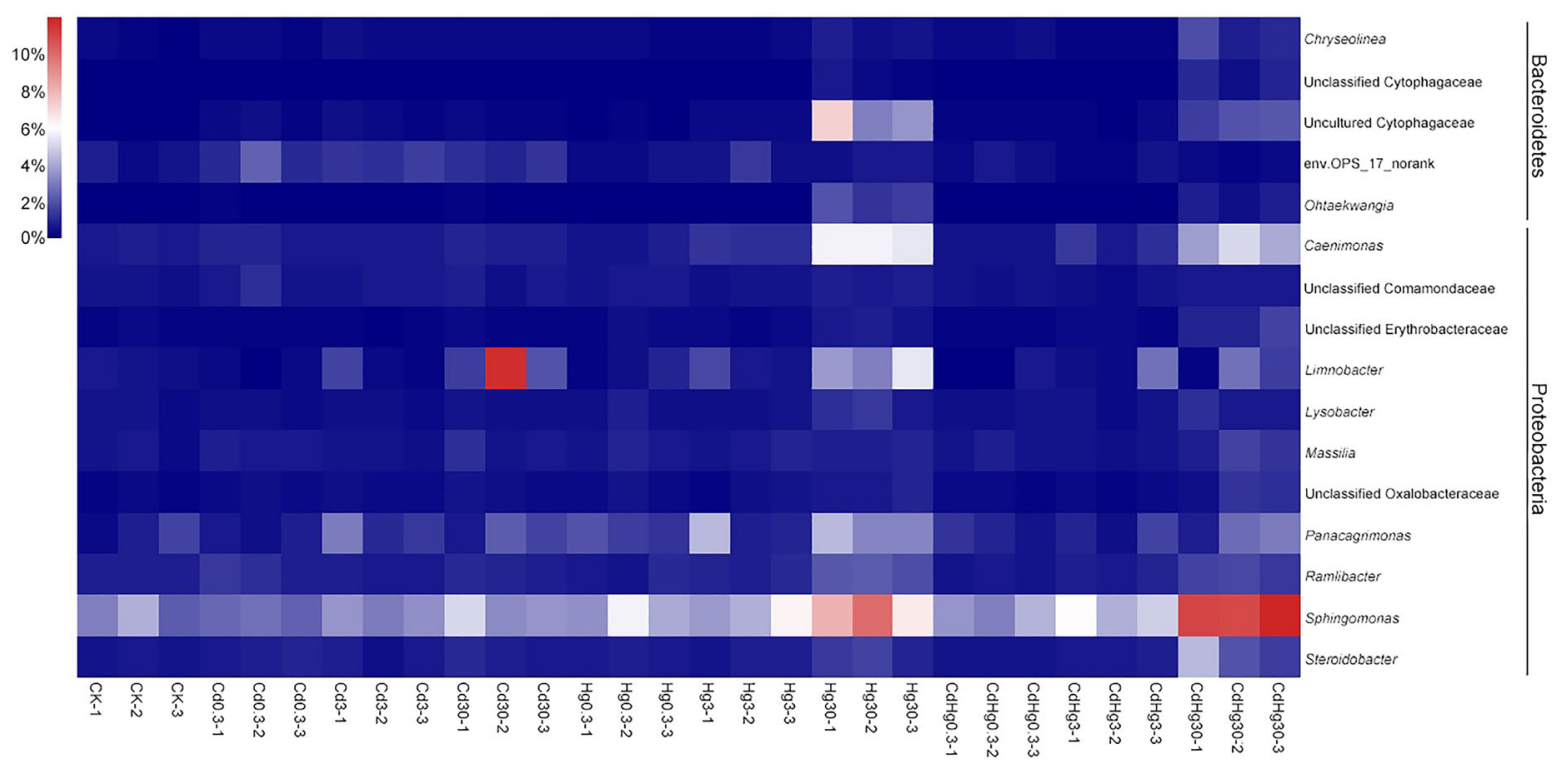

Fig. 6 Heat maps of the 23 most sensitive bacterial genera and 16 most resistant bacterial genera identified in different treatments. The color intensity in each panel represents the relative abundance as the

\section{Differences in predictive metabolism of $\mathrm{Cd}$ - and/or Hg-treated soils}

PICRUSt analysis was used to predict metagenomic function in soils based on the KEGG orthology (KO) predictions. We focused on the predictive relative abundances of KOs assigned to the main bacterial metabolism (Fig. 7). The predictive metabolic changes were prominent in the treatment groups with the highest levels of $\mathrm{Hg}\left(30 \mathrm{mg} \mathrm{Hg} \mathrm{kg}{ }^{-1}\right.$ and $30 \mathrm{mg}$ of $\mathrm{Cd}$ and $30 \mathrm{mg}$ of $\mathrm{Hg} \mathrm{kg}^{-1}$ ). $\mathrm{Hg} 30$ and $\mathrm{CdHg} 30$ percentage of total bacterial sequences in each sample. a Twenty-three most sensitive classified genera. b Sixteen most resistant classified genera

exhibited the lowest values for cysteine and methionine metabolism, streptomycin biosynthesis, starch and sucrose metabolism, peptidase levels, pantothenate and CoA biosynthesis, selenocompound metabolism, and terpenoid backbone biosynthesis. These two treatments exhibited the highest phenylalanine metabolism, folate biosynthesis, one-carbon metabolism based on folate, glutathione metabolism, aminobenzoate degradation, caprolactam degradation, and metabolism of xenobiotics by cytochrome P450. In addition, the highest levels of $\mathrm{Cd}$ and $\mathrm{Hg}$ both resulted in the lowest 

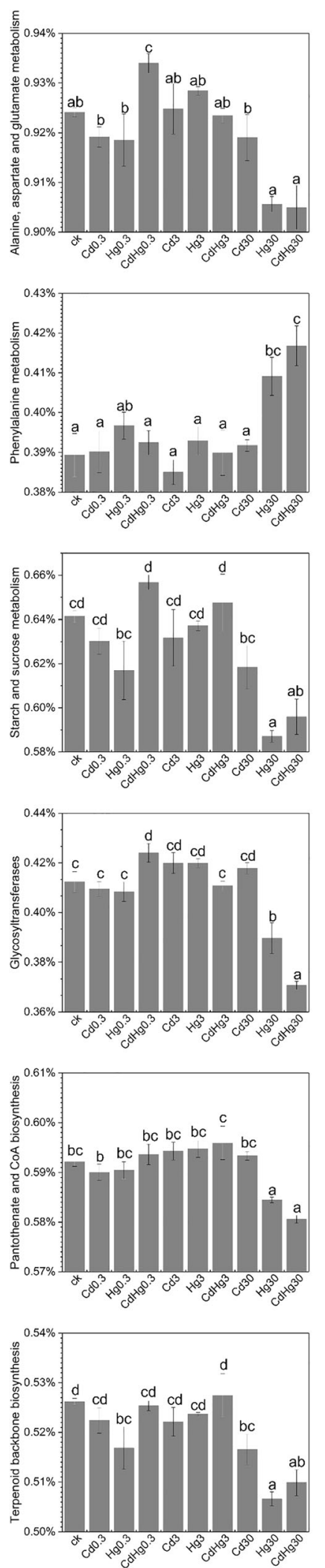
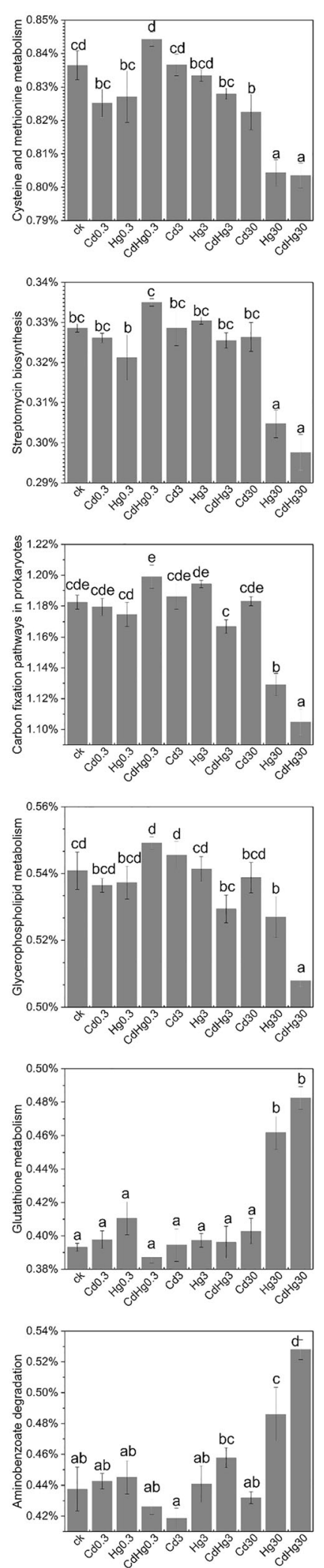
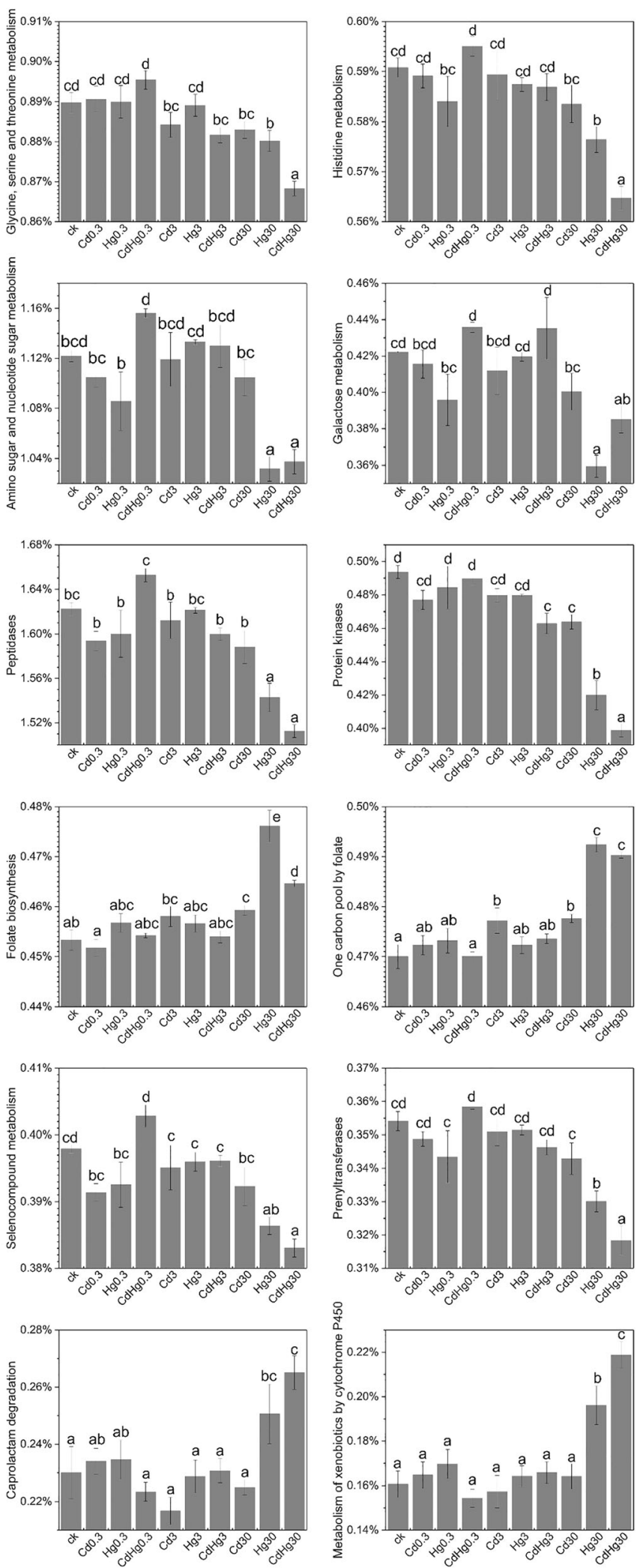

Fig. 7 The main predictive metabolism that is significantly influenced by heavy metals in soils. The error bars show the standard error of three subsamples for each soil sample. Different letters indicate significant differences $(p<0.05$, Duncan) 
values of glycine, serine, and threonine metabolism; histidine metabolism; carbon fixation in prokaryotes; protein kinase levels; glycosyltransferase levels; glycerophospholipid metabolism; and prenyltransferase levels.

\section{Discussion}

The lowest $\mathrm{Cd}$ and $\mathrm{Hg}$ concentrations used in this study (up to $0.3 \mathrm{mg} \mathrm{Cd} \mathrm{and} / \mathrm{or} \mathrm{Hg} \mathrm{kg}^{-1}$ dry soil) were within the range that has often been detected in soils, and the $\mathrm{Cd}$ and $\mathrm{Hg}$ concentrations in the soil samples were $0.30 \mathrm{mg} \mathrm{kg}^{-1}$ and $0.0633 \mathrm{mg} \mathrm{kg}^{-1}$, respectively, which were 3.70 -fold and 4.52-fold higher than the background values of Huaibei City (the background levels of $\mathrm{Cd}$ and $\mathrm{Hg}$ in Huaibei City were $0.081 \mathrm{mg} \mathrm{kg}^{-1}$ and $0.014 \mathrm{mg} \mathrm{kg}^{-1}$, respectively). The high concentration used (up to $3 \mathrm{mg} \mathrm{Cd}$ and/or $\mathrm{Hg} \mathrm{kg}^{-1}$ dry soil) was within the range observed for contaminated soils (Türkdoğan et al. 2003). The highest level (30 mg Cd and/or $\mathrm{Hg} \mathrm{kg}^{-1}$ dry soil) of heavy metals used in our study corresponded to the amounts supplied in other microcosm experiments on agricultural (Hollender et al. 2003; Pan and Yu 2011) or tropical (Harris-Hellal et al. 2009) soils and has been observed in heavily contaminated fields (Gosar and Teršič 2012).

Previous studies found that soil enzyme activities, soil respiration, and microbial abundance/biomass were sensitive to changes in soil quality (Bowles et al. 2014; Mbuthia et al. 2015). Soil enzymes including soil urease activity, acid phosphatase activity, dehydrogenase activity, and catalase activity were used to estimate the adverse effects of various pollutants on soil health (Masto et al. 2009). Similarly, in this study, urease, acid phosphatase, dehydrogenase, and catalase activities varied widely among different treatments, and the enzyme activities decreased with increasing concentrations of heavy metals. In particular, urease and dehydrogenase activity were strongly inhibited by heavy metals, confirming the results of previous studies (Wiatrowska et al. 2015; Xian et al. 2015). Previous research has shown that soil enzyme activities decrease with increasing availability of heavy metals (Xian et al. 2015). Similarly, it was shown that $\mathrm{Cd}$ had a distinct inhibitory effect on urease, acid phosphatase, and catalase activities (Mao et al. 2015; Xin et al. 2017). The enzyme activities decreased in the presence of heavy metals, which can interact with the enzyme-substrate complex and denature the enzyme or interact with active sites of proteins ( $\mathrm{Li}$ and Liu 2015).

Soil basal respiration is a good indicator of total soil microbial activity (Caravaca et al. 2017) which was often inhibited in heavy-metal-contaminated soils (Xu et al. 2019). In this study, heavy metal toxicity induced the death of a large number of microorganisms, and the surviving microorganisms required energy supply for survival (Fashola et al. 2016) and resistance to heavy metal toxicity (Ayangbenro and Babalola
2017). In general, the toxicity generated by heavy metals may suppress or even kill sensitive soil microorganisms and lead to decreased soil respiration (Rajapaksha et al. 2004). However, increased soil respiration in the presence of certain level of heavy metal contamination has also been observed ( $\AA$ kerblom et al. 2007). The increased basal respiration in soil treated with $\mathrm{Cd}$ and $\mathrm{Hg}$ could also be the consequence of increased maintenance energy requirement or decreased metabolic and substrate use efficiency (Renella et al. 2007).

Previous studies have indicated that high levels of heavy metals could induce DNA damage, such as single- and double-strand breaks and base modification, in organisms (Ates et al. 2004) and influence the microbiota directly via transformation of population size, diversity, and structure (Deng et al. 2015). In contrast, the NMDS showed no difference in fungal communities among samples. The fungal communities exhibited relatively low sensitivity to $\mathrm{Cd}$ and $\mathrm{Hg}$ in all the treatments. Rieder and Frey (2013) also found that fungi are more resistant than bacteria to long-term heavy metal contamination. In addition, fungal growth and species diversity are generally reduced along with increasing concentrations of heavy metals in soils (Li et al. 2012). Many fungi can also tolerate increased soil concentrations of heavy metals (Li et al. 2012), including Hg (Kelly et al. 2006). Meharg (2003) suggested that the organic acids exuded by fungi may form complexes with metals present in soils, thereby reducing the associated metal toxicity.

Soil bacteria are generally considered to be highly sensitive to metal contaminants (Jin et al. 2015), although some bacteria have developed a range of heavy metal resistance mechanisms. In our study, gradual shifts in bacterial community composition induced by $\mathrm{Cd}$ and $\mathrm{Hg}$ gradients were observed, indicating the presence of dose-related effects, as previously reported (Macdonald et al. 2011). We found that different bacterial groups responded differently to $\mathrm{Cd}$ and $\mathrm{Hg}$ contaminations; specifically, Actinobacteria, Acidobacteria, Candidate divisions WS3, Chloroflexi, Gemmatimonadetes, Proteobacteria, and Thermotogae exhibited sensitivity to $\mathrm{Cd}$ and $\mathrm{Hg}$ contaminations in soils. These groups exhibited $\mathrm{Cd}$ and $\mathrm{Hg}$ sensitivity and thus can be recognized as indicators of $\mathrm{Cd}$ and $\mathrm{Hg}$ contaminations. The sensitivity of Acidobacteria to heavy metals has been reported in previous studies (Macdonald et al. 2011). The absence of a lipid outer membrane and specialized secretion systems in Chloroflexi (Sutcliffe 2011) might account for the sensitivity of these bacteria to heavy metals. Bacteroidetes and Proteobacteria exhibited high tolerance and reached the highest proportion in the $\mathrm{Hg} 30, \mathrm{Cd} 30$, and $\mathrm{CdHg} 30$ treatments (Fig. 6b). Extrusion of heavy metal ions by efflux systems, segregation by thiolcontaining molecules, and reduction to oxidative states with reduced toxicity (Harichová et al. 2012) are common bacterial metal resistance mechanisms. In addition, this study suggested that the high concentration of $\mathrm{Hg}$ exerted additional pressure 
on the bacterial community, which was not apparent with $\mathrm{Cd}$ exposure, and the effects of $\mathrm{Cd} / \mathrm{Hg}$ on bacterial community structure were stronger than those of $\mathrm{Hg}$ alone because of synergistic interactions in the combined metal treatments.

Soil bacterial metabolism mainly includes material metabolism and energy metabolism (Edirisinghe et al. 2016). All the predictive metabolic pathways expected for carbon fixation in prokaryotes were closely related to material metabolism and were severely affected by heavy metals. These bacterial material metabolism pathways are important for the functions of the soil ecosystem (Wagg et al. 2014; Creamer et al. 2016), and the changes in bacterial material metabolism indicated the occurrence of soil degradation under heavy metal stress.

In conclusion, the responses of different soil enzymes to elevated heavy metal concentrations differed. Soils containing the highest level of the combination of $\mathrm{Cd}$ and $\mathrm{Hg}$ exhibited the lowest soil enzyme activities. The heavy metals significantly decreased the microbial abundance but stimulated respiration, and the elevated $\mathrm{Hg}$ levels led to increased fungal abundance. In addition, the structures of the bacterial communities but not fungal communities were influenced by heavy metal addition, and the predictive bacterial metabolism was perturbed by heavy metals.

Funding This work was financially supported by the National Natural Science Foundation of China (41373108), the Science and Technology Support Program of Anhui Provinces (1608085QD79), the Science and Technology Project of Land and Resources of Anhui Province (2013-K07), and the Key Scientific and Technological Project of Huaibei Mining Industry (Group) Co., Ltd. (HBKY-2014-01).

\section{Compliance with ethical standards}

\section{Research involving human participants and/or animals N/A}

Disclaimer All the authors have seen the manuscript and approved the publication of this work in the journal.

Conflict of interest The authors declare that they have no conflict of interest.

\section{References}

Åkerblom S, Bååth E, Bringmark L, Bringmark E (2007) Experimentally induced effects of heavy metal on microbial activity and community structure of forest mor layers. Biol Fertil Soils 44:79-91

Ates I, Sinan Suzen H, Aydin A, Karakaya A (2004) The oxidative DNA base damage in testes of rats after intraperitoneal cadmium injection. Biometals 17:371-377

Ayangbenro A, Babalola O (2017) A new strategy for heavy metal polluted environments: a review of microbial biosorbents. Int J Environ Res Public Health 14:94

Bowles TM, Acosta-Martínez V, Calderón F, Jackson LE (2014) Soil enzyme activities, microbial communities, and carbon and nitrogen availability in organic agroecosystems across an intensivelymanaged agricultural landscape. Soil Biol Biochem 68:252-262
Caravaca F, Lozano Z, Rodríguez-Caballero G, Roldán A (2017) Spatial shifts in soil microbial activity and degradation of pasture cover caused by prolonged exposure to cement dust. Land Degrad Dev 28:1329-1335

Chen J, He F, Zhang X, Sun X, Zheng J, Zheng J (2014) Heavy metal pollution decreases microbial abundance, diversity and activity within particle-size fractions of a paddy soil. FEMS Microbiol Ecol 87:164-181

Chen L, Zhang W, Zhang R, Lin K, He L, Wu L (2015) The bioavailability and adverse impacts of lead and decabromodiphenyl ether on soil microbial activities. Environ Sci Pollut Res 22:12141-12149

Chodak M, Gołębiewski M, Morawska-Płoskonka J, Kuduk K, Niklińska M (2013) Diversity of microorganisms from forest soils differently polluted with heavy metals. Appl Soil Ecol 64:7-14

Creamer RE, Hannula SE, Leeuwen JPV, Stone D, Rutgers M, Schmelz RM, Ruiter PCd, Hendriksen NB, Bolger T, Bouffaud ML, Buee M, Carvalho F, Costa D, Dirilgen T, Francisco R, Griffiths BS, Griffiths R, Martin F, Silva PMd, Mendes S, Morais PV, Pereira C, Philippot L, Plassart P, Redecker D, Römbke J, Sousa JP, Wouterse M, Lemanceau P (2016) Ecological network analysis reveals the interconnection between soil biodiversity and ecosystem function as affected by land use across Europe. Appl Soil Ecol 97:112-124

Deng L, Zeng G, Fan C, Lu L, Chen X, Chen M, Wu H, He X, He Y (2015) Response of rhizosphere microbial community structure and diversity to heavy metal co-pollution in arable soil. Appl Microbiol Biotechnol 99:8259-8269

dos Santos LMR, Gloaguen TV, Fadigas FdS, Chaves JM, Martins TMO (2017) Metal accumulation in soils derived from volcanosedimentary rocks, Rio Itapicuru Greenstone Belt, northeastern Brazil. Sci Total Environ 601(602):1762-1774

Edirisinghe JN, Weisenhorn P, Conrad N, Xia F, Overbeek R, Stevens RL, Henry CS (2016) Modeling central metabolism and energy biosynthesis across microbial life. BMC Genomics 17:568

Fashola MO, Ngole-Jeme VM, Babalola OO (2016) Heavy metal pollution from gold mines: environmental effects and bacterial strategies for resistance. Int J Environ Res Public Health 13

Frey B, Rieder SR (2013) Response of forest soil bacterial communities to mercury chloride application. Soil Biol Biochem 65:329-337

Gao Y, Zhou P, Mao L, Zhi Y-e, Shi W-j (2010) Assessment of effects of heavy metals combined pollution on soil enzyme activities and microbial community structure: modified ecological dose-response model and PCR-RAPD. Environ Earth Sci 60:603-612

Gosar M, Teršič T (2012) Environmental geochemistry studies in the area of Idrija mercury mine, Slovenia. Environ Geochem Health 34:2741

Guan SY (1986) Soil enzyme and the assessment methodology. Press of Agriculture, Beijing, pp 275-323

Harichová J, Karelová E, Pangallo D, Ferianc P (2012) Structure analysis of bacterial community and their heavy-metal resistance determinants in the heavy-metal-contaminated soil sample. Biologia 67: $1038-1048$

Harris-Hellal J, Vallaeys T, Garnier-Zarli E, Bousserrhine N (2009) Effects of mercury on soil microbial communities in tropical soils of French Guyana. Appl Soil Ecol 41:59-68

Hollender J, Althoff K, Mundt M, Dott W (2003) Assessing the microbial activity of soil samples, its nutrient limitation and toxic effects of contaminants using a simple respiration test. Chemosphere 53:269 275

Jan FA, Ishaq M, Ihsanullah I, Asim SM (2010) Multivariate statistical analysis of heavy metals pollution in industrial area and its comparison with relatively less polluted area: a case study from the City of Peshawar and district Dir Lower. J Hazard Mater 176:609-616

Jiang B, Adebayo A, Jia J, Xing Y, Deng S, Guo L, Liang Y, Zhang D (2019) Impacts of heavy metals and soil properties at a Nigerian ewaste site on soil microbial community, vol 362, pp 187-195 
Jin Z, Li Z, Li Q, Hu Q, Yang R, Tang H, Li M, Huang B, Zhang J, Li G (2015) Canonical correspondence analysis of soil heavy metal pollution, microflora and enzyme activities in the $\mathrm{Pb}-\mathrm{Zn}$ mine tailing dam collapse area of Sidi village, SW China. Environ Earth Sci 73: 267-274

Kelly DJA, Budd K, Lefebvre DD (2006) The biotransformation of mercury in pH-stat cultures of microfungi. Can J Bot 84:254-260

Khan S, El-Latif Hesham A, Qiao M, Rehman S, He J-Z (2010) Effects of $\mathrm{Cd}$ and $\mathrm{Pb}$ on soil microbial community structure and activities. Environ Sci Pollut Res 17:288-296

Lee I-S, Kim OK, Chang Y-Y, Bae B, Kim HH, Baek KH (2002) Heavy metal concentrations and enzyme activities in soil from a contaminated Korean shooting range. Int J Environ Res Public Health 94: 406-411

Li Y, Liu F-c (2015) Heavy metal concentrations and enzymatic activities in the functional zone sediments of Haizhou Bay, Lianyungang, Jiangsu, China. Environ Monit Assess 187:660

Li H-Y, Li D-W, He C-M, Zhou Z-P, Mei T, Xu H-M (2012) Diversity and heavy metal tolerance of endophytic fungi from six dominant plant species in a $\mathrm{Pb}-\mathrm{Zn}$ mine wasteland in China. Fungal Ecol 5:309315

Li Z, Ma Z, van der Kuijp TJ, Yuan Z, Huang L (2014) A review of soil heavy metal pollution from mines in China: pollution and health risk assessment. Sci Total Environ 468(469):843-853

Macdonald CA, Clark IM, Zhao F-J, Hirsch PR, Singh BK, McGrath SP (2011) Long-term impacts of zinc and copper enriched sewage sludge additions on bacterial, archaeal and fungal communities in arable and grassland soils. Soil Biol Biochem 43:932-941

Mao L, Tang D, Feng H, Gao Y, Zhou P, Xu L, Wang L (2015) Determining soil enzyme activities for the assessment of fungi and citric acid-assisted phytoextraction under cadmium and lead contamination. Environ Sci Pollut Res 22:19860-19869

Masto RE, Chhonkar PK, Singh D, Patra AK (2009) Changes in soil quality indicators under long-term sewage irrigation in a subtropical environment. Environ Geol 56:1237-1243

Mbuthia LW, Acosta-Martínez V, DeBruyn J, Schaeffer S, Tyler D, Odoi E, Mpheshea M, Walker F, Eash N (2015) Long term tillage, cover crop, and fertilization effects on microbial community structure, activity: implications for soil quality. Soil Biol Biochem 89:24-34

Meharg AA (2003) The mechanistic basis of interactions between mycorrhizal associations and toxic metal cations. Mycol Res 107: $1253-1265$

Moreno JL, Garcia C, Hernandez T (2003) Toxic effect of cadmium and nickel on soil enzymes and the influence of adding sewage sludge. Eur J Soil Sci 54:377-386

Pan J, Yu L (2011) Effects of Cd or/and Pb on soil enzyme activities and microbial community structure. Ecol Eng 37:1889-1894

Pérez-de-Mora A, Burgos P, Madejón E, Cabrera F, Jaeckel P, Schloter M (2006) Microbial community structure and function in a soil contaminated by heavy metals: effects of plant growth and different amendments. Soil Biol Biochem 38:327-341
Rajapaksha RMCP, Tobor-Kapłon MA, Bååth E (2004) Metal toxicity affects fungal and bacterial activities in soil differently. Appl Environ Microbiol 70:2966-2973

Renella G, Chaudri AM, Falloon CM, Landi L, Nannipieri P, Brookes PC (2007) Effects of $\mathrm{Cd}, \mathrm{Zn}$, or both on soil microbial biomass and activity in a clay loam soil. Biol Fertil Soils 43:751-758

Rieder SR, Frey B (2013) Methyl-mercury affects microbial activity and biomass, bacterial community structure but rarely the fungal community structure. Soil Biol Biochem 64:164-173

Šajn R, Aliu M, Stafilov T, Alijagić J (2013) Heavy metal contamination of topsoil around a lead and zinc smelter in Kosovska Mitrovica/ Mitrovicë, Kosovo/Kosovë. J Geochem Explor 134:1-16

Shang W, Tang Q, Zheng L, Cheng H (2016) Chemical forms of heavy metals in agricultural soils affected by coal mining in the Linhuan subsidence of Huaibei Coalfield, Anhui Province, China. Environ Sci Pollut Res 23:23683-23693

Sutcliffe IC (2011) Cell envelope architecture in the Chloroflexi: a shifting frontline in a phylogenetic turf war. Environ Microbiol 13: 279-282

Türkdoğan MK, Kilicel F, Kara K, Tuncer I, Uygan I (2003) Heavy metals in soil, vegetables and fruits in the endemic upper gastrointestinal cancer region of Turkey. Environ Toxicol Pharmacol 13: $175-179$

Wagg C, Bender SF, Widmer F, van der Heijden MGA (2014) Soil biodiversity and soil community composition determine ecosystem multifunctionality. Proc Natl Acad Sci U S A 111:5266-5270

Wang Y, Shi J, Wang H, Lin Q, Chen X, Chen Y (2007) The influence of soil heavy metals pollution on soil microbial biomass, enzyme activity, and community composition near a copper smelter. Ecotoxicol Environ Saf 67:75-81

Wiatrowska K, Komisarek J, DłużEwski P (2015) Effects of heavy metals on the activity of dehydrogenases, phosphatases and urease in naturally and artificially contaminated soils. J Elem 20:743-756

Xian Y, Wang M, Chen W (2015) Quantitative assessment on soil enzyme activities of heavy metal contaminated soils with various soil properties. Chemosphere 139:604-608

Xin J, Zhao X, Tan Q, Sun X, Wen X, Qin S, Hu C (2017) The effects of cadmium exposure on cadmium fractionation and enzyme activities in the rhizosphere of two radish cultivars (Raphanus sativus L.). Bull Environ Contam Toxicol 98:290-295

Xu Y, Seshadri B, Bolan N, Sarkar B, Ok YS, Zhang W, Rumpel C, Sparks D, Farrell M, Hall T, Dong Z (2019) Microbial functional diversity and carbon use feedback in soils as affected by heavy metals. Environ Int 125:478-488

Publisher's note Springer Nature remains neutral with regard to jurisdictional claims in published maps and institutional affiliations. 